\title{
錠用における吸液速度の測定
}

\author{
須那 滋 \\ 四国鉄道病院保健管理部衛生武臨室*
}

\section{Measurement of Liquid Absorbing Speed of Tablets}

\author{
SHIGERU SUNA \\ Hygienic Laboratory, Health Service Division, \\ Shikoku Hospital of Japanese National Railways*
}

(Received November 14, 1985)

\begin{abstract}
A simple method for measuring the volume of liquid absorbed by tablets was devised and applied to the liquid penetration test with commercialized tablets. In case of the penetration of ethyl acetoacetate, the swelling of tablets was not observed, and the $\mathrm{V}^{2} \mathrm{vs}$. $t$ plots showed good linearity where $\mathrm{V}$ is the volume of liquid taken up. expressed in $\mu 1$. and $\mathrm{t}$ is the time in second. In case of the water penetration, tablets swelled remarkably and the $\mathrm{V}^{2}$ vs. $t$ plots showed the concave lines, but the $\log \mathrm{V}$ vs. $\log \mathrm{t}$ plots showed a good linearity. The slopes of the regression lines obtained from the $\log \mathrm{V}$ vs. $\log \mathrm{t}$ plots were in the range of 0.5 to 1.0.
\end{abstract}

Keywords_- liquid absorption of tablets; penetration test; swelling of tablets; commercialized tablets; disintegrating agent

\section{はじめに}

錠斉の崩壊過程において，第一段階として空筫毛細管 を通じて錠剂内部への液体の浸入が起こる．この浸透速 度 (濡れ速度) が錠剤の崩壊の速さを決定する大きな要 因であり, 理論的には Washburn 式と呼ばれる(1)式で 示される.11

$$
\mathrm{L}^{2}=\mathrm{R} r \cos \theta \mathrm{t} / 2^{\eta}
$$

$\mathrm{L}$ : 浸透距離, $\mathrm{R}$ : 錠剤の毛管径

$r$ : 液体の表面張力, $\eta:$ 液体の粘度

$\theta:$ 錠剂内壁と液体の接触角, $\mathrm{t}$ : 時間

Fukuoka ら² は, 油圧プレスで実験的に作製した錠剂 の一端を水に浸潰し, 浸透上昇する距離と時間の関係を 調べ，水と接触することにより膨潤を起こす結晶セルロ 一ス錠以外は(1)式に従った漫透が行われることを示し た、しかしながら，この方法においては，錠剤がある程 度大きくないと測定が不正確になりやすい，また，錠剤

* 高松市西内町 2-30；2-30, Nishiuchi-machi, Takamatsu-shi, 760 Japan
の円形に沿って浸透させるため, 漫透断面積が時間と共 に変化する点も問題となる. したがって, 小形の円形錠 が多い市販錠への適用は困難と思われる.

著者は，錠剤内部へ浸透する液体の体積を経時的に測 定することができる簡便な装置を考案し，市販錠におけ る吸液速度の測定を試みたので報告する。

$$
\text { 実 験 の 部 }
$$

\section{1. 荘}

図 1 に測定装置を示したが, 本装固は液だめビンと吸 液量測定用メスピペットを接続しただけの簡単な構造 で，作製は容易である，また，さまざまな大きさの錠剂 に適用でき, とくに小形錠で吸液量の少ない場合は 2 3 錠を用いることにより，測定が十分可能となる。

\section{2. 測定方法}

まず, 液だめビンに液体を満たし，恒温槽中で目的の 液温とした後, メスピペットをつなぎ液体を導く、さら に液だめビンのロまで液体を追加し，ビンのロにろ紙を のせる（気泡が入り込まぬよら注意する）. 次いで，吸 い取り紙等をろ紙に接着させ，過剩の液を吸い取り,メ スピペットの目盛りに合わせる。しばらく放置し, 液量 


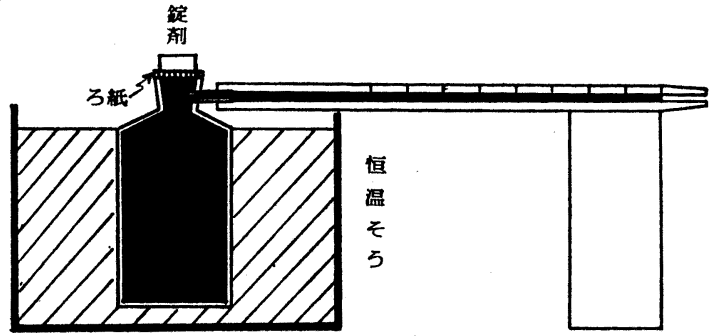

図 1. 錠郕吸液速度測定装膡

飞変化がなく一定であることを確かめた後，錠剤をろ紙 上飞そっとのせ，同時にストップウォッチを押し，吸液 量 $\mathrm{V}(\mu \mathrm{l})$ と時間 $\mathrm{t}(\mathrm{sec})$ を記録する。

\section{3. 料}

実験に供した錠剤は次のとおりである。ストロカイン 錠(エーザイ), ネルボン錠®・5 mg (三共), ワーファ リン錠・・1 mg（エーザイ）, パナス®錠（グレラン製 薬), ユリノーム錠 (鳥居薬品), ダイアジッド錠『・ $100 \mathrm{mg}$ (日本新薬).

漫透させた液体は, アセト酢酸エチル（和光純薬, 試 薬 1 級, bp : $181^{\circ} \mathrm{C}, \mathrm{d}: 1.021$ at $\left.25^{\circ} \mathrm{C}\right)$ 扰よび蒸留水 であった。

\section{結果}

\section{1. アセセ酢酸エチルの漫透}

アセト酢酸エチルを浸透させた場合は，実験したいず れの錠剤も，膨潤などの外観変化はみられなかった。ネ ルボン錠, ワーファリン錠の液温 $20^{\circ} \mathrm{C} に$ 打ける測定結 果を $\mathrm{V}^{2}$ vs. $\mathrm{t}$ プロットしたものを図 2 , 因 3 亿示した が，いずれもきれいな值線となった．次にストロカイン 錠を同一シールより 4 錠取り，〈り返し測定した結果を 表 1 亿，その V vs. $t$ プロットを図 4 亿示した．各錠の 吸液速度は，C.V. $20 \%$ 程度のばらつきが見られるが， $V^{2}$ vs. $\mathrm{t}$ プロットによりそれぞれきれいな直線となっ た。これらの実験結果より，アセト酢酸エチルを錠剂に 漫透させた場合は, $\mathrm{V}^{2}=\mathrm{kt}(\mathrm{k}:$ 定数) なる関係式で示 し得ることがわかった．また，本測定装置は，吸液速度 の測定と同時に浸透終了後の総吸液量を知ることができ

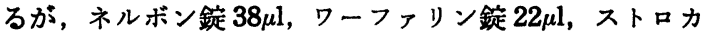
イン錠 $100 \mu \mathrm{l}$ (表1）であった.

\section{2. 水の湜遥}

市眅錠に水を漫透させた場合，ほとんどの錠剤で明ら かな膨潤が認められた。図 5 は、ストロカイン錠に $20^{\circ} \mathrm{C}$ 及び $37^{\circ} \mathrm{C}$ の水を浸透させた 結 果 ( 3 錠の平均値) であ る. $V^{2}$ vs. $t$ プロットは直線とはならずに，二次曲線に

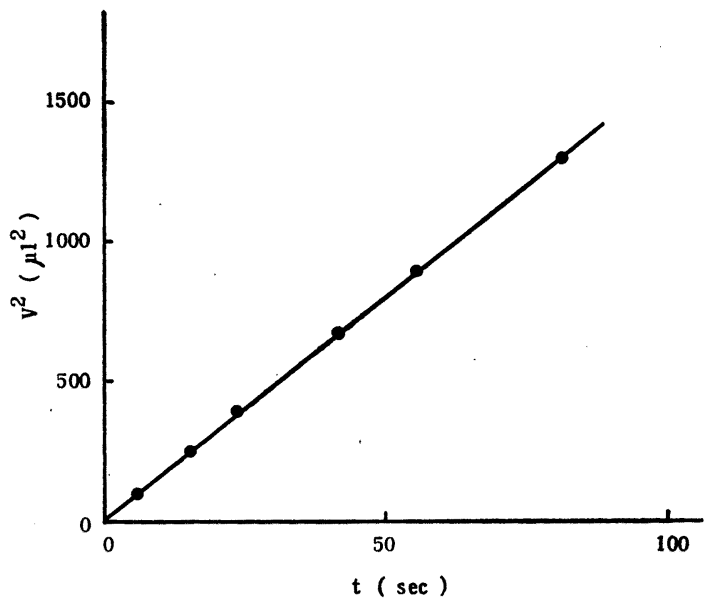

図 2.ネルボン錠にわけるアセト酢酸エチルの浸透 (at $20^{\circ} \mathrm{C}$ )

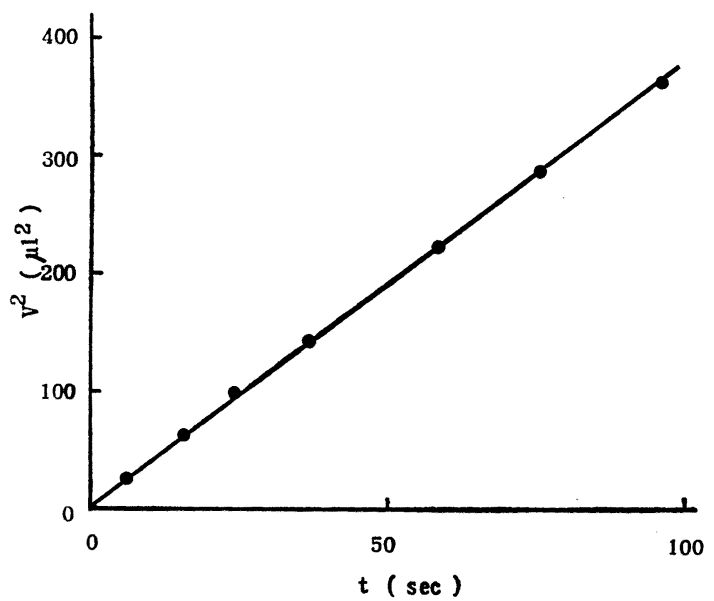

図 3. ワーファリン錠におけろアセト酿酸エチルの 浸透 (at $20^{\circ} \mathrm{C}$ )

近いカーブを示したが，両対数プロットできれいな直線 となった。ストロカイン錟における水の総吸液量は, $20^{\circ} \mathrm{C}$ す $37^{\circ} \mathrm{C}$ す約 $400 \mu 1$ で，アセ卜醀酸エチルを浸透さ せた場合の 4 倍であった. ワーファリン鏔, バナス錠, ユリノーム錠などにおいても，両対数ブロットは良好な 直線性を示し，したがって， $\log V=a \log t+b(a, b$ : 回帰俰数) なる式にあてはめることが可能であった。

表 2 亿各錠に护ける浸透実験より得られた回帰俰数を

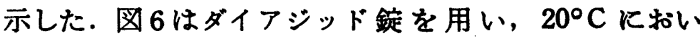
て10回くり返し測定した結果を両対数プロットしたるの で，いずれる良好な植線となるが，勾配、は $0.811 \pm$ 0.027 (平均土標準偏差) とほぼ一定值が得られた。ま 
表 1.ストロカイン錠におけるアセト酢酸エチルの浸透（at $20^{\circ} \mathrm{C）}$

\begin{tabular}{crrrrrr}
\hline \hline \multirow{2}{*}{$\mathrm{V}(\mu \mathrm{l})$} & \multicolumn{6}{c}{$\mathrm{t}(\mathrm{sec})$} \\
\cline { 2 - 7 } & \multicolumn{1}{c}{1} & \multicolumn{1}{c}{3} & \multicolumn{1}{c}{4} & av. & S.D. \\
\hline \hline 20 & 15.3 & 21.8 & 25.7 & 17.6 & 20.1 & 4.6 \\
30 & 34.0 & 47.8 & 55.8 & 39.0 & 44.2 & 9.6 \\
40 & 61.5 & 86.0 & 93.4 & 62.3 & 75.8 & 16.3 \\
50 & 96.3 & 133.7 & 139.6 & 94.5 & 115.8 & 23.7 \\
60 & 138.9 & 187.7 & 192.2 & 134.0 & 163.2 & 31.0 \\
70 & 189.6 & 254.8 & 254.7 & 180.8 & 220.0 & 40.3 \\
80 & 248.2 & 332.9 & 326.3 & 233.8 & 285.3 & 51.6 \\
90 & 317.8 & 422.9 & 406.1 & 290.4 & 359.3 & 65.1 \\
\hline 稜吸液量 & 104 & 95 & 97 & 103 & & \\
$(\mu 1)$ & & & & & & \\
\hline
\end{tabular}

av.：平均值，S.D.：標準偏差

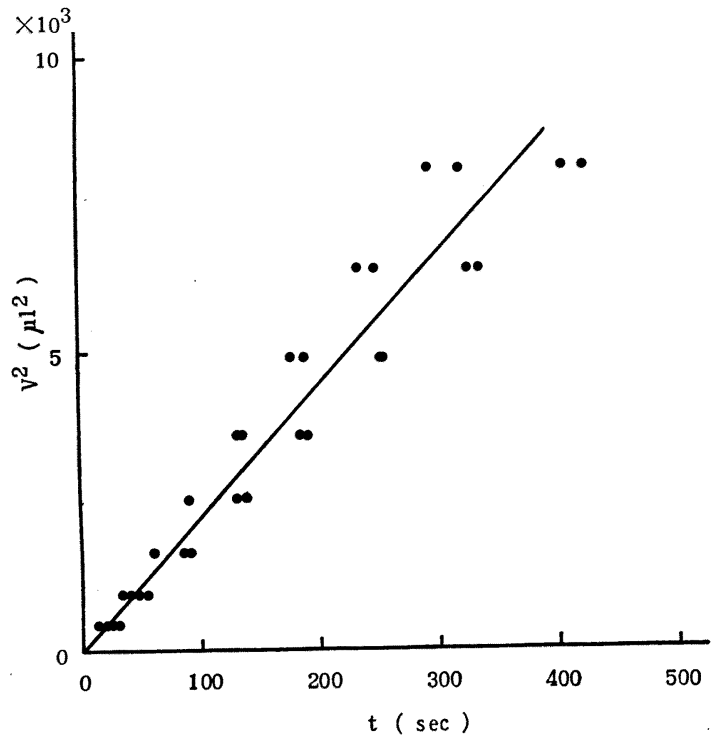

図 4. ストロカイン錠におけるアセト酢酸エチルの 漫透 (at $20^{\circ} \mathrm{C}$ )

た，切片 b と錠剤重量の間に有意な負の相関が得られた (図7).なお，ノギス（読取限度: $1 / 20 \mathrm{~mm}$ ) による 計測では，錠斉の厚さは一定とみなすことができた。

\section{考察}

アセト酢酸エチルの浸透においては， $\mathrm{V}^{2}=\mathrm{kt}(\mathrm{k}:$ 定 数) なる関係を得た。これは膨潤等の構造変化が起こら
ず，Washburn 式に従った漫透が行われたためと考えら れる、しかし，Vは浸透に関与するすべての毛細管を代 表する值であるのに対して，Lは径の大きい毛細管にお ける浸透をあらわす.2したがってVよりLを推定するこ とはできないが， $V^{2}$ vs. $\mathrm{t}$ プロットにより得られる $\mathrm{k}$ 值 は，浸透しやすさを示す指標として利用できる．また， 総吸液量は, 浸透に関与する空吵毛細管の体積を意味 し, 錠剤の空吵構造を推定する上で役立つと思われる. 次に, 水を浸透させた場合, 膨潤などの構造変化を生じ るため, $\mathrm{V}^{2}$ vs. $\mathrm{t}$ プロットは二次曲線に近いカーブとな った・これは，Fukuoka ら²) の検討における結晶セルロ 一ス錠の場合と同様な結果である．さらにVと $\mathrm{t}$ を両対 数軸にプロットしたところ，試験したいずれの錠斉にお いても, 良好な直線関係が得られ, 回帰直線式の勾配 a は 0.5 から 1.0 の間の値を示した（表 2 ).

ところで, 回帰直線式 $\log V=a \log \mathrm{t}+\mathrm{b}$ を真数の 式にもどせば， $\mathrm{V}=10^{\mathrm{b}} \cdot \mathrm{t}^{\mathrm{a}}$ となり，原点を通る曲線で 示される（ただし， $\mathrm{a}=1$ の時は直線となる）. ここで $\mathrm{a}=0.5$ は, Washburn 式に従った浸透が行われる時に 成立する. 一方，膨潤などが生じる場合は $a>0.5$ とな り, 数值が大きいほど構造変化が吸液速度へ及ぼす影響 が大であると考えられる.

なお，ダイアジッド錠をくり返し測定した結果，ほぼ 一定の $\mathrm{a}$ 值が得られることより, 同一組成の錠剤におい ては, 膨潤等の構造変化が再現性良く行われることが推 察される. 次に bは $\mathrm{t}$ が非常に小さい時 $(\mathrm{t}=1 \mathrm{sec})$ の $\log \mathrm{V}$ である（この時 $\mathrm{V}=10^{\mathrm{b}} \mu \mathrm{l}$ となる）が, Washburn 

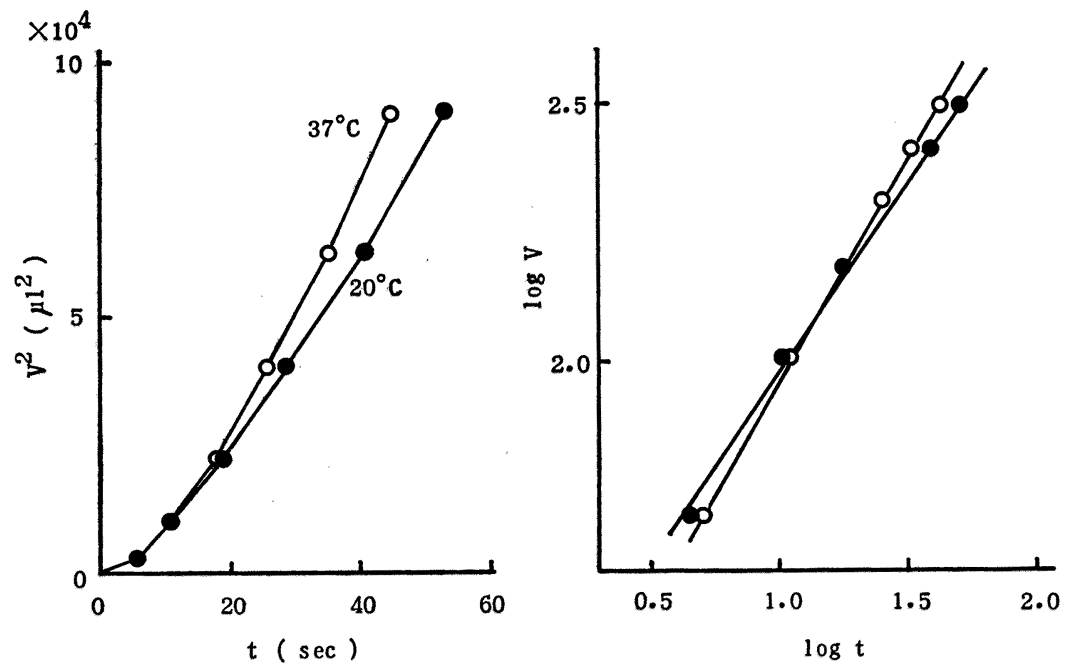

図 5. ストロカイン錠における水の浸透 (at $20^{\circ} \mathrm{C}, 37^{\circ} \mathrm{C}$ )

表 2. 両対数プロットにより得られた回帰係数

\begin{tabular}{|c|c|c|c|c|}
\hline \multirow{2}{*}{ 錠 剂名 } & \multicolumn{2}{|c|}{$20^{\circ} \mathrm{C}$} & \multicolumn{2}{|c|}{$37^{\circ} \mathrm{C}$} \\
\hline & a & b & a & b \\
\hline ストロカイン錠※ & 0.74 & 1.21 & 0.84 & 1.11 \\
\hline ワーフアリン錠※※ & 0.55 & 0.17 & 0.71 & 0.02 \\
\hline パナス錠※※ & 0.62 & -0.22 & 0.69 & -0.02 \\
\hline ユリノーム錠※※ & 0.93 & -0.78 & 0.91 & -0.26 \\
\hline
\end{tabular}

※: 3 錠の平均值, ※※: 2 錠の平均值

$\mathrm{a}, \mathrm{b}:$ 回福保数, $\log \mathrm{v}=\mathrm{a} \log \mathrm{t}+\mathrm{b}$

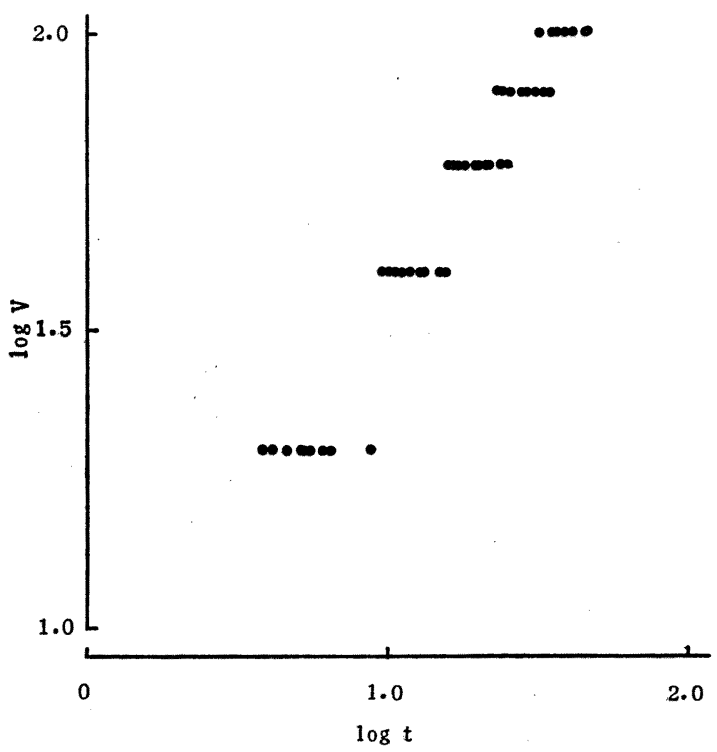

因 6. ダイアジッド錠における水の浸透 (at 20 C)

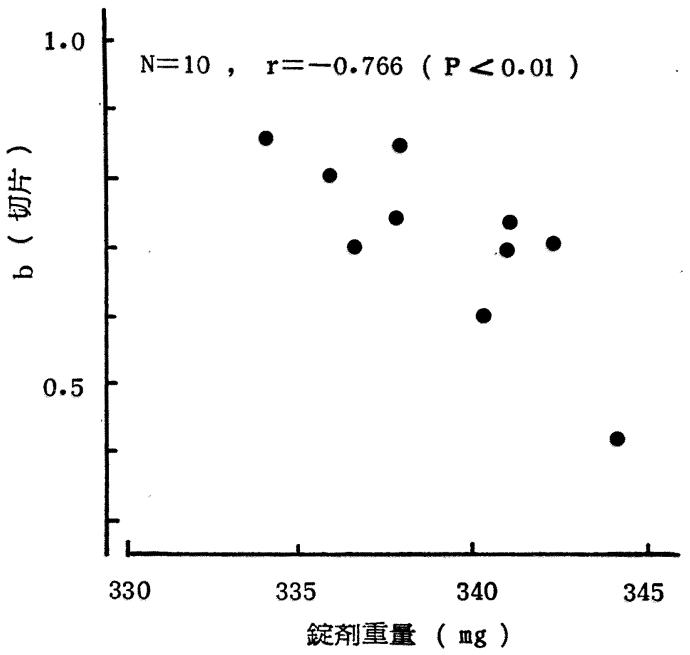

図 7.ダイアジッド錠における切片 b と錠剤重量の 関係

式の定数項と同様に, 錠剂の毛管径や液体の粘度, 接触 角, 表面張力などと密接な関係があるすのと考える（た だし, 浸透する液体の粘度, 接触角, 表面張力が変らな いと仮定した場合).さらに, 真数にもどした吸液速度 式をみれば，aが一定の場合，吸液速度はbに依存する ことがわかる（なお， b 值が正のとき $10^{\mathrm{b}}>1$ となり， 負の值を示す時は $0<10^{\mathrm{b}}<1$ となる). ダイアジッド錠 において， b と錠剤重量の間に有意な負相関を得たが， 厚さが一定の錠㶡において, 重量の大きいるのは空隐率 が減少し, 平均毛管径が小さくなり，液体が浸透しにく くなるためと考える. 
以上, 今回著者が試みた方法は, 簡便であるため広く 現場において利用でき，しかも錠昘の崩壊現象に関する 多くの情報が得られる.とくに，錠剤の品質のばらつき や，経時的な劣化を解析する上で，有用な手段であると 考える.

䪭辞 本研究に対し, 数多くの示唆を与えてください ました徳島大学薬学部, 松浦 博教授に深謝いたしま
す.

$$
\text { 文献 }
$$

1）仲井由宣編：“新しい薬剤学,”広川書店, 1972, p. 345 .

2) E. Fukuoka, et al. : Chem. Pharm. Bull., 29, 205 (1981).

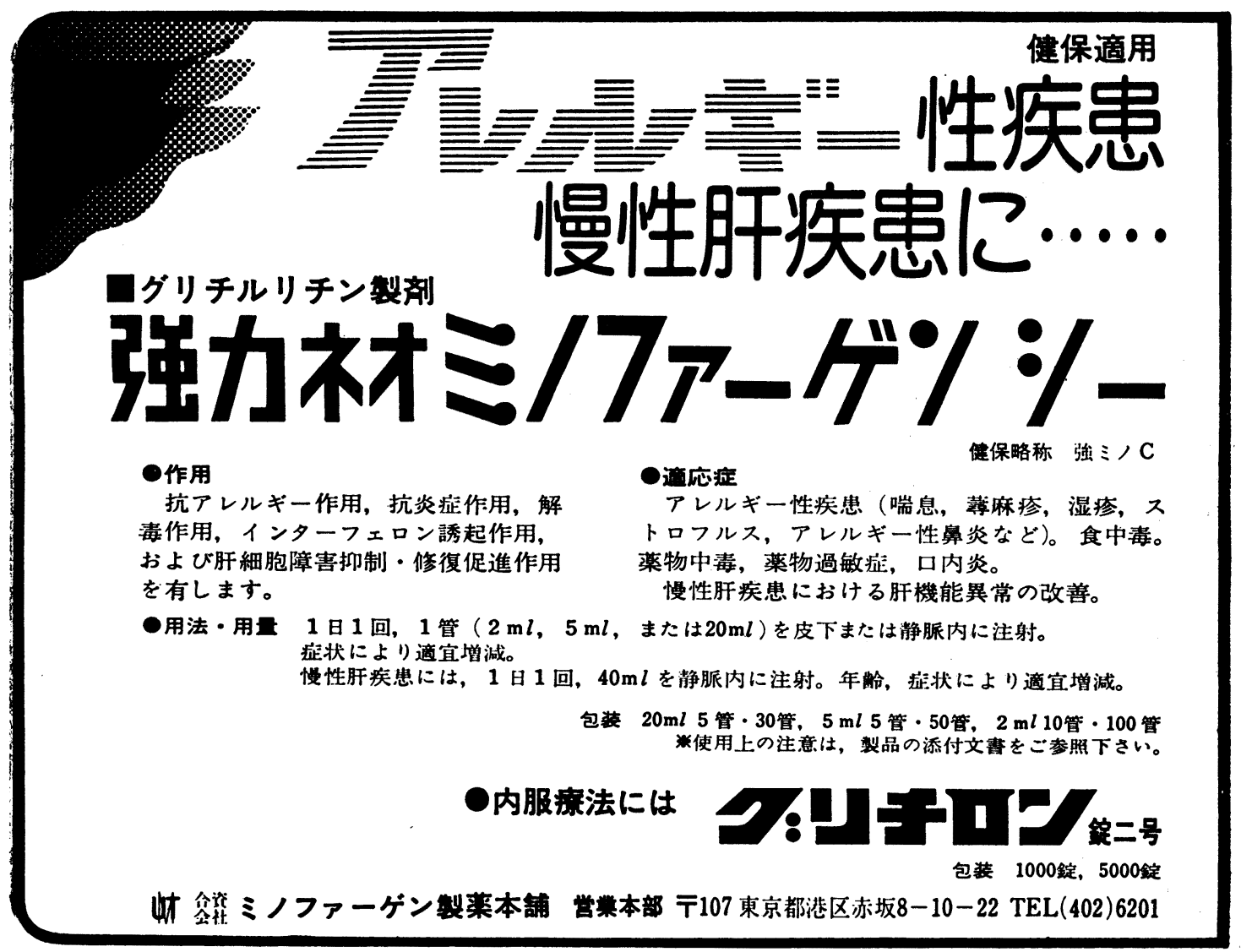

